\title{
ANALISIS PERILAKU PENGGUNA SISTEM INFORMASI PENGETAHUAN OBAT BUATAN UNTUK KEBUTUHAN SWAMEDIKASI
}

\author{
Ryan Randy Suryono ${ }^{1)}$, Yeni Agus Nurhuda ${ }^{2)}$, Muhammad Ridwan ${ }^{3)}$ \\ ${ }_{1,2,3}$ Sistem Informasi, Fakultas Teknik dan Ilmu Komputer \\ 1,2,3 Universitas Teknokrat Indonesia, Bandar Lampung, Indonesia \\ ${ }^{2}$ S3 Ilmu MIPA FMIPA, Universitas Lampung, Indonesia \\ Email: ${ }^{1}$ ryan@teknokrat.ac.id, ${ }^{2}$ agus.nurhuda@teknokrat.ac.id, ${ }^{3}$ iwan.robin@gmail.com
}

\begin{abstract}
Abstrak
Swamedikasi merupakan upaya pengobatan secara mandiri yang dilakukan masyarakat untuk mengobati dirinya sendiri. Namun bila tidak dilakukan dengan tepat justru menimbulkan masalah baru yaitu adanya resistensi bakteri dan ketergantungan. Kesalahan prediksi juga mengakibatkan munculnya penyakit baru karena efek samping obat antara lain seperti gangguan sistem pencernaan, reaksi hipersensitif, serta memungkinkan terjadi keracunan. Pelaksanaan swamedikasi, diprediksi akan menimbulkan kesalahan penggunaan obat (medication error) yang disebabkan keterbatasan pengetahuan masyarakat akan obat dan penggunaanya. Untuk itu, pada penelitian terdahulu dibangun sebuah sistem informasi obat buatan yang berisi tentang data-data dan pengetahuan tentang obat buatan yang dapat diakses masyarakat secara bebas dan mudah. Namun pada penerapannya, belum diketahui apakah sistem informasi tersebut dapat meningkatkan rasionalitas dan keterampilan dalam melakukan swamedikasi. Penelitian ini bertujuan untuk mengetahui apakah sistem informasi obat buatan yang telah dibangun dapat meningkatkan rasionalitas dan keterampilan masyarakat. Pendekatan dilakukan dengan melakukan quasi eksperimen terhadap 150 responden, yaitu memberikan treatment dengan menyebar kuesioner sebelum dan sesudah sistem informasi obat buatan digunakan. Dari kesenjangan tersebut, dilakukan pendekatan kualitatif kepada empat informan, untuk menggali lebih dalam apakah terjadi perubahan perilaku pengguna sistem informasi untuk kebutuhan swamedikasi. Hasil penelitian menunjukan bahwa Sistem Informasi Obat Buatan yang diimplementasikan dapat meningkatkan rasionalitas dan keterampilan masyarakat dalam melakukan swamedikasi berdasarkan perbandingan nilai sebelum treatment sebesar 3,95 menjadi 8,77 pada skala 0 9,00. Hal ini terjadi karena sistem meтuat informasi lengkap seputar gejala, penyakit, dan obat-obatan.
\end{abstract}

Kata Kunci: perilaku pengguna sistem informasi, swamedikasi, quasi eksperimen.

\section{Pendahuluan}

Swamedikasi adalah upaya pengobatan secara mandiri yang dilakukan masyarakat untuk mengobati dirinya sendiri [2]. Namun bila tidak dilakukan dengan benar, justru dapat menimbulkan masalah yaitu penyakit tidak dapat sembuh dan muncul penyakit baru karena efek samping obat antara lain pendarahan sistem pencernaan, reaksi hipersensitif, serta meningkatnya tingkat keracunan [3].

Data faktual menunjukkan bahwa $66 \%$ orang sakit di Indonesia melakukan swamedikasi sebagai usaha pertama dalam menanggulangi penyakitnya. Persentase tersebut cenderung lebih tinggi dibandingkan $44 \%$ penduduk yang langsung berobat jalan ke dokter [1]. Meski begitu, tingginya angka ini harus tetap diwaspadai, pasalnya pada pelaksanaan swamedikasi, diprediksi akan banyak terjadi kesalahan penggunaan obat (medication error) yang disebabkan keterbatasan pengetahuan masyarakat akan obat dan penggunaanya [2]. Untuk itu, pada penelitian sebelumnya, dilakukan pengembangan sistem informasi yang berisi tentang data-data dan pengetahuan tentang obat buatan yang dapat diakses masyarakat secara bebas dan mudah [5]. Namun pada penerapannya, belum diketahui apakah sistem informasi tersebut dapat meningkatkan rasionalitas dan keterampilan dalam melakukan swamedikasi.

Tujuan dari penelitian ini untuk mengetahui apakah sistem informasi obat buatan yang telah dibangun dapat meningkatkan rasionalitas dan keterampilan masyarakat dalam melakukan swamedikasi. Metode yang dilakukan pada penelitian ini adalah dengan melakukan quasi eksperimen dan pendekatan kualitatif. Quasi Eksperimen dilakukan dengan cara memberikan test berupa kuesioner awal yang harus diisi pelaku swamedikasi lalu diberikan sosialisasi dan pelatihan penggunaan sistem informasi obat buatan. Setelah program dikenalkan kepada responden, dilakukan test kedua dengan kuesioner yang sama. Dari perbedaan hasil pretest dan posttest, dilakukan pendekatan kualitatif dengan melakukan wawancara mendalam untuk melihat apakah terjadi perubahan prilaku pengguna sistem informasi obat buatan untuk kebutuhan swamedikasi.

\section{Kajian Teori}

\section{Swamedikasi}

Swamedikasi berarti mengobati segala keluhan pada diri sendiri dengan obat-obatan yang dibeli bebas di apotek atas inisiatif sendiri tanpa nasehat dokter. Obat untuk swamedikasi meliputi obat-obat yang dapat 
digunakan tanpa resep yang meliputi obat wajib apotek (OWA), obat bebas terbatas (OBT) dan obat bebas (OB). Apoteker dalam pelayanan OWA diwajibkan memenuhi ketentuan dan batasan tiap jenis obat per pasien yang tercantum dalam daftar OWA 1 dan OWA 2 wajib pula membuat catatan pasien serta obat yang diserahkan apoteker hendaknya memberikan informasi penting tentang dosis, cara pakai, kontra indikasi, efek samping dan lain-lain yang perlu diperhatikan oleh pasien [9].

\section{Keterampilan}

Keterampilan adalah kemampuan untuk menggunakan akal, pikiran dan ide dan kreatifitas dalam mengerjakan, mengubah ataupun membuat sesuatu menjadi lebih bermakna sehingga menghasilkan sebuah nilai dari hasil pekerjaan tersebut. Faktor-faktor yang dapat mempengaruhi keterampilan secara langsung yaitu, motivasi, pengalaman, dan keahlian [10].

\section{Rasionalitas}

Rasionalitas merupakan konsep normatif yang mengacu pada kesesuaian keyakinan seseorang dengan alasan seseorang untuk percaya, atau tindakan seseorang dengan alasan seseorang untuk bertindak. Penggunaan obat dikatakan rasional jika memenuhi kriteria antara lain, tepat diagnosis, tepat indikasi, tepat pemilihan obat, tepat dosis, tepat informasi, dan tepat penilaian kondisi pasien (Kementrian Kesehatan RI, 2011).

\section{Sistem Informasi Obat Buatan}

Sistem Informasi Obat Buatan merupakan sebuah situs yang bermanfaat sebagai sarana media pendidikan kesehatan kepada masyarakat tentang penggunaan obat-obatan dalam swamedikasi. Untuk melakukan swamedikasi secara aman, rasional, efektif dan terjangkau masyarakat perlu menambah bekal pengetahuan dan melatih keterampilan dalam praktik swamedikasi. Masyarakat memerlukan informasi yang jelas dan terpercaya agar penentuan kebutuhan jenis atau jumlah obat dapat diambil berdasarkan alasan yang rasional [5].

\section{Metode}

Penelitian ini berfokus untuk mengetahui apakah sistem informasi yang diimplementasikan dapat meningkatkan keterampilan masyarakat dalam melakukan swamedikasi dan mengetahui apakah implementasi sistem informasi yang dikembangkan mempengaruhi rasionalitas masyarakat dalam swamedikasi. Dengan melakukan kuasi eksperimen, penelitian ini melakukan percobaan terhadap kelompok eksperimen. Kepada tiap kelompok eksperimen dikenakan perlakuan-perlakuan tertentu dengan kondisi-kondisi yang dapat di kontrol [6]. Tabel 1 merupakan demografi responden.

Awalnya, 150 responden diberikan pretest berupa kuesioner tentang perilaku swamedikasi. Responden adalah masyarakat yang sudah pernah melakukan swamedikasi atau melakukan pengobatan sendiri tanpa resep dokter. Teknik pengambilan sample ini menggunakan teknik purposive sampling. Kemudian, hasil kuesioner tersebut dihitung dan dirata-rata. Setelah mendapatkan nilai awal, responden diberi pelatihan dan sosialisasi penggunaan sistem informasi obat buatan. Kemudian, diberikan posttest untuk melihat perbandingan pemahaman sebelum dan sesudah diberikan perlakuan. Dari hasil tersebut, dilakukan wawancara secara mendalam kepada 4 informan secara acak yang memiliki kesenjangan nilai test. Informan pada penelitian ini tidak dibatasi oleh umur dan jenis kelamin serta telah melakukan swamedikasi.

Tabel 1. Demografi Responden

\begin{tabular}{|c|c|c|}
\hline Variabel & Total $(n=150)$ & $(\%)$ \\
\hline \multicolumn{3}{|l|}{ Gender } \\
\hline Man & 71 & $47 \%$ \\
\hline Women & 79 & $53 \%$ \\
\hline \multicolumn{3}{|l|}{ Age } \\
\hline a. $16-20$ th & 70 & $47 \%$ \\
\hline b. $21-25$ th & 65 & $43 \%$ \\
\hline c. $26-30$ th & 8 & $5 \%$ \\
\hline d. $31-40$ th & 6 & $4 \%$ \\
\hline e. $41-50$ th & 2 & $1 \%$ \\
\hline f. $>51$ & 0 & $0 \%$ \\
\hline \multicolumn{3}{|l|}{ Educational Background } \\
\hline a. Senior High School & 133 & $89 \%$ \\
\hline b. Diploma & 3 & $2 \%$ \\
\hline c. Bachelor & 8 & $5 \%$ \\
\hline d. Master & 6 & $4 \%$ \\
\hline e. Doctoral & 0 & $0 \%$ \\
\hline \multicolumn{3}{|l|}{ Job } \\
\hline a. Government Employees & 1 & $1 \%$ \\
\hline b. Entrepreneur & 5 & $3 \%$ \\
\hline c. Employees & 17 & $11 \%$ \\
\hline d. Non Job & 127 & $85 \%$ \\
\hline
\end{tabular}

Dengan kata lain, Penelitian ini juga menggunakan pendekatan kualitatif dengan perspektif kajian sistem informasi karena peneliti bermaksud memahami situasi sosial secara mendalam, menemukan pola, dan menggali lebih luas implikasi dari fenomena swamedikasi. Pada pendekatan ini, peneliti membuat suatu gambaran kompleks, meneliti kata-kata, laporan terinci dari pandangan responden, dan melakukan studi pada situasi yang dialami[7] [8].

Gambar 1 merupakan tampilan menu utama Sistem Informasi Obat Buatan. Pengguna sistem dapat menginputkan data Penyakit, Gejala, maupun Obat.

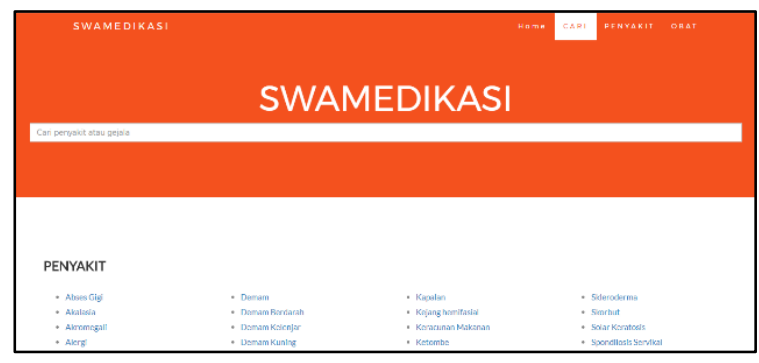

Gambar 1. Tampilan Menu Utama [5] 
Pengguna dapat mencari penyakit yang yang diinginkan dengan mengklik menu penyakit yang terdapat di sebelah kanan atas tampilan dari website. Setelah mengklik menu penyakit, selanjutnya akan muncul tampilan seluruh daftar penyakit yang terdapat pada sistem informasi pengetahuan obat buatan untuk kebutuhan swamedikasi Berikut adalah tampilan daftar penyakit.

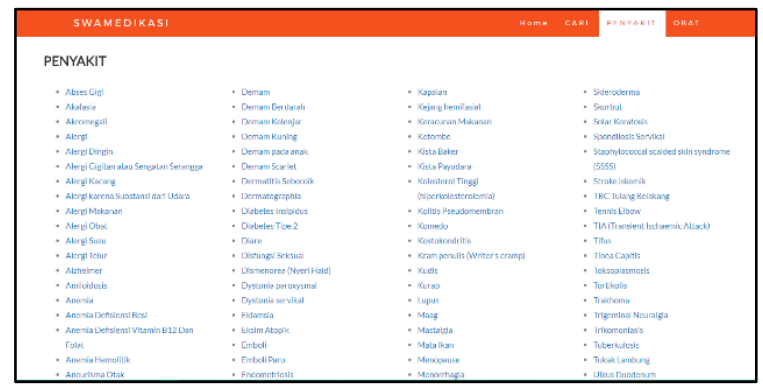

Gambar 2. Tampilan Daftar Penyakit [5]

\section{Temuan dan Hasil}

\section{Kuasi Eksperimen}

Berdasarkan percobaan yang dilakukan, didapat nilai rata-rata sebelum proses treatment sebesar 3,95 dari skala 9. Hal ini membuktikan bahwa kurangnya pengetahuan responden tentang swamedikasi. Sedangkan nilai rata-rata sesudah proses treatment diperoleh angka 8,77 dari skala 9. Gambar 2 merupakan grafik hasil kuasi eksperimen.

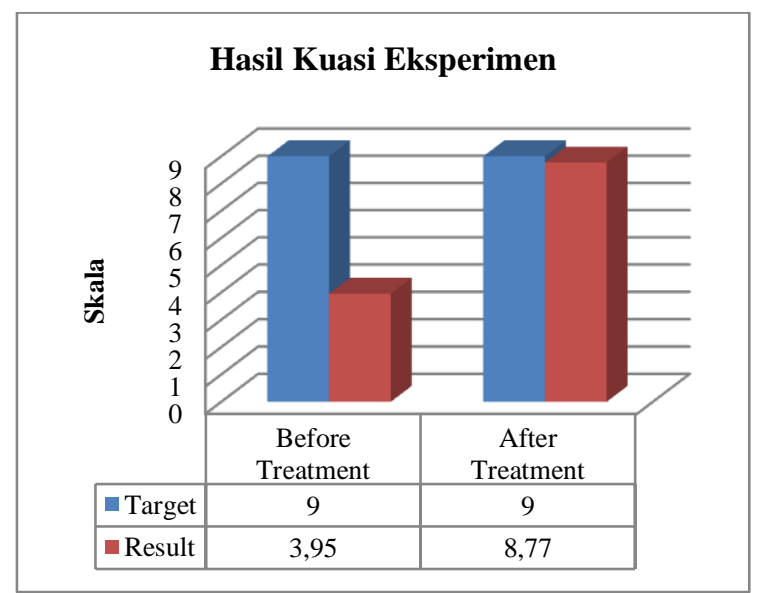

Gambar 2. Grafik Hasil Kuasi Eksperimen

\section{Hasil Wawancara}

Berdasarkan hasil wawancara, diperoleh hasil sebagai berikut:

Temuan 1 - Penggunaan Sistem Informasi Obat Buatan dapat meningkatkan rasionalitas masyarakat dalam swamedikasi

Sistem Informasi yang dirancang, berisi informasi tentang obat, gejala, dan penyakit. Hal ini dapat membantu pengguna dalam melakukan swamedikasi. Informasi tentang obat, gejala, dan penyakit tersebut memungkinkan pengguna secara tepat melakukan diagnosis, tepat indikasi, tepat memilih obat, tepat menentukan dosis, tepat informasi, dan tepat menilai kondisi pasien. Rasionalitas pengguna didukung dengan informasi mengenai kontradiksi yang tercantum pada aplikasi.

\section{Temuan 2 - Penggunaan Sistem Informasi Obat Buatan dapat meningkatkan keterampilan masyarakat dalam swamedikasi}

Sistem Informasi yang dirancang, bermanfaat menambah pengetahuan pengguna. Pengguna dapat mengakses situs kapan saja untuk mengetahui informasi obat-obatan. Hal ini membuat pengguna terampil dalam menentukan obat yang tepat untuk penyakitnya. Dengan adanya sistem informasi ini, motivasi pengguna untuk melakukan tindakan sesuai prosedur meningkat. Tidak hanya itu, pengalaman keberhasilan melakukan swamedikasi dapat menambah keahlian seseorang untuk menentukan jenis obat yang dibutuhkan tanpa harus pergi ke dokter.

\section{Diskusi}

Setelah melakukan analisis dari hasil temuan, maka dapat diusulkan konseptual model berdasarkan pengalaman pengguna. Hasil wawancara mengkonfirmasi bahwa penggunaan Sistem Informasi Obat Buatan dapat meningkatkan rasionalitas dan keterampilan masyarakat dalam swamedikasi.

Rasionalitas Swamedikasi didukung oleh indikator tepat diagnosis, tepat indikasi, tepat pemilihan obat, tepat dosis, tepat informasi, dan tepat penilaian kondisi pasien. Hal ini dapat mengurangi kesalahan penggunaan obat. Seperti yang kita ketahui, pemberian obat terhadap pasien, tidak bisa sembarangan. Sistem informasi ini membantu pengguna dalam menangani penyakit yang diderita masyarakat.

Berdasarkan informasi yang ditampilkan pada sistem, keterampilan pengguna dalam swamedikasi pun meningkat. Hal ini disebabkan oleh kesadaran pengguna terhadap manfaat pembangunan sistem. Jika pengguna berfikir sistem yang dibangun memberikan kemudahan, maka motivasi dalam menggunakan sistem dapat meningkat. Setelah menggunakan sistem ini, maka terbentuklah pengalaman positif yang menyebabkan sistem dapat digunakan kembali. Keberhasilan mendiagnosis penyakit, gejala, dan obat dengan menggunakan sistem informasi ini, dapat meningkatkan keahlian pengguna sistem. Dengan kata lain, sistem ini berhasil memberikan manfaat bagi penggunanya.

Gambar 3 mengilustrasikan model penelitian yang dapat dibangun. 


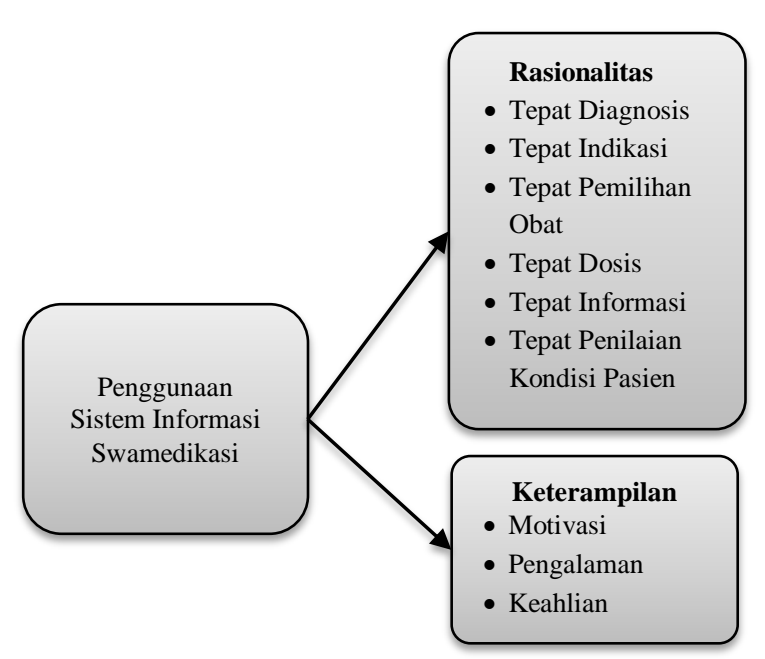

Gambar 3. Model Konseptual yang diusulkan

\section{Kesimpulan}

Penelitian ini memiliki kontribusi bagi masyarakat, pengembang aplikasi, dan secara khusus bagi paramedis. Pertama, masyarakat dapat merasakan manfaat dari implementasi sistem. Hal ini terjadi karena sistem memuat informasi lengkap seputar gejala, penyakit, dan obat-obatan. Kedua, bagi pengembang aplikasi, sistem yang dirancang telah memberikan manfaat bagi pengguna. Pengembang dapat menambah database penyakit, gejala, dan obatobatan untuk menyajikan informasi yang lengkap seputar penggunaan obat buatan. Ketiga, sistem ini juga dapat digunakan kelompok paramedis sebagai referensi dan kamus obat-obatan dalam menentukan obat yang tepat untuk pasien.

Penelitian ini hanya membahas perilaku pengguna sistem berdasarkan kuasi eksperimen dan pendekatan kualitatif, maka penelitian selanjutnya dapat mengembangkan model penelitian ini dan menguji model tersebut dengan kuantitatif. Selain itu, penelitian selanjutnya juga dapat mengukur kualitas informasi, kualitas sistem, dan kualitas layanan pada sistem informasi pengetahuan obat buatan ini.

\section{Daftar Pustaka}

[1] Badan Pusat Statistik, 2009, Survei Sosial Ekonomi Nasional (SUSENAS), Jakarta.

[2] Depkes RI, 2006. Pedoman penggunaan obat bebas dan bebas terbatas. Jakarta: Depkes.

[3] Galato, D., Galafassi, L.M., Alano, G.M., Trauthman, S.C., 2009, Responsible Selfmedication: Review of The Process of Pharamaceutical Attendance, Brazilian Journal of Pharmaceutical Sciences, 45(4):p.625-633.

[4] Kemenkes RI, 2011. Modul Penggunaan Obat Rasional (POR). Jakarta: Kementrian Kesehatan RI.

[5] Nurhuda, Y. A., Suryono, R. R. \& Friansyah, D. K., 2017. Rancangan Arsitektur Sistem Berbasis Pengetahuan Obat Buatan Untuk Kebutuhan Swamedikasi. Prosiding Annual Research Seminar 2017 (Computer Science and ICT), Volume 3 No.1.

[6] Sugiyono, P., 2014. Memahami Penelitian Kualitatif. Bandung: Alfabeta.

[7] Suryono, R. R. \& Subriadi, A. P., 2016. Investigation on The Effect of User's Experience to Motivate Playing Online Games. Journal of Theoretical and Applied Information Technology, Vol.86. No.1

[8] Suryono, R.R. Perilaku Pemain Game Online terhadap Pembelian Virtual Item. Jurnal Sistem Informasi, Vol 5 No. 5. Hlm 578 - 584.

[9] Tjay, T. H., Rahardja, Kirana. 2007. Obat-Obat Penting, Kasiat, Penggunaan dan Efek-Efek Sampingnya, Edisi Keenam, 262, 269-271. Jakarta: PT Elex Media Komputindo.

[10] Widyatun, 2005. Ilmu Perilaku. Rineka Cipta: Jakarta. 